\title{
MS-9 頭蓋底髄膜腫の手術
}

\section{1. 鞍結節髄膜腫の手術}

兵庫医科大学脳神経外科

有田 憲生

鞍結節髄膜腫はよく知られた疾患ではあるが，手術用顕微 鏡導入以後, 多数例を扱った報告は限られている。 その理由 の 1 つは, 下垂体腺腫と比較すると, 鞍結節髄膜腫では術後 視機能の改善が必ずしも得られない点であろう。下垂体腺腫 では，視神経が鞍隔膜を介し間接的に圧排挙上されている. それに対し，鞍結節䯣膜腫では視神経が腫瘍に直接圧排され たり，取り囲まれているうえに，視神経管入口部近傍で下方 からは腫瘍により，上方からは falciform ligament および A1 により拘厄されている。ささらに多くの例では，腫瘍は視神経 管内に伸展している。このような点より, 鞍結節部髄膜腫に 対しては，必要に応じて視神経管開放を行わないと視神経の 減圧は十分には行えない。過去 20 年間に経験した 45 例を対 象として，手術手技と治療成績について報告する。

\section{Clinoidal meningioma の手術}

独立行政法人国立病院機構九州医療センター脳神経外 科臨床研究部

井上＼cjkstart亨

Clinoidal meningioma を安全に手術するためには, 海綿静脈 洞・蝶形骨洞を含む前床突起近傍 - carotid dural ring • carotid cave の微小外科解剖に習熟する必要がある。また，視 神経, 視交叉, ophthalmic segment を含めた内頸動脈の走行・ 分枝についても熟知しておくことが肝要である. Anterior choroidal artery, 後交通動脈は腫瘍により圧排伸展されてい る. Clinoidal meningioma の手術は, 腫煬の大きさや固さによ り手術の難易度が大きく左右される。特に,大きな腫瘍では, 前大脳動脈および中大脳動脈の穿通枝の温存に注意を払う必 要がある。微小外科解剖からみたわれわれの clinoidal meningioma への治療戦略を呈示し, また, 前床突起切除の際の 骨削開用超音波手術装置（ソノペット）の有用性についても 紹介する。

\section{3. 斜台錐体部腫瘍に対する petrosal approach}

横浜市立大学医学部脳神経外科

坂田 勝巳, 山本 勇夫

斜台錐体部髄膜腫に対する手術到達法としては, anterior petrosal approach (APA), posterior petrosal approach (PTP) に大別され, 病変の部位と大きさ, 静脈還流パターンによつ て到達経路を選択する，到達法の違いを踏まえ，手術解剖お よび手術手技のポイントを解説する。開頭範囲は，原則とし て前者は側頭開頭 + anterior petrosectomy, 後者は側頭後頭下 開頭＋mastoidectomy であるが，雨者は連続した術野であり， 症例に応じ臨機応変に術野を展開する (combined petrosal approach）ことが重要である。そのためには，側頭骨の解剖 を熟知しておくことは必要不可欠である。後頭蓋窩下方の進 展する例では retrosigmoid route を用いる場合もある.基本的 には上錐体静脈洞を切離し，小脳テントを切開し腫瘍に到達 する，髄膜腫の摘出においては部位にかかわらず 3D の原則 (devasculatization, decompression, dissection) を遵守するこ とが重要である. 